\title{
Human Rights, Refugees and Internally Displaced Persons: The UN Commission on Human Rights
}

\author{
Tim Wichert
}

\begin{abstract}
This article argues that protecting refugees and internally displaced persons (IDPs) is an issue of universal human rights. It then suggests the urgent need for the UN Commission on Human Rights, working in collaboration with the United Nations High Commissioner for Refugees (UNHCR) and member states of the United Nations, to. play more important roles in protecting and enhancing human rights. It also stresses the importance of appropriate follow-up to the calls for more commitment and better actions in this area.

\section{Précis}

Cet article présente une argumentation selon laquelle la protection des réfugiés et des personnes déplacées en deçà des limites $d^{\prime} u n$ territoire national est une question de droits humains universels. Il signale aussi le besoin urgent pour la Commission des droits de la Personne en collaboration avec le Haut Commissariat des Nations Unies aux réfugiés et les états membres des Nations Unies, de jouer un rôle accru dans la protection et la valorisation des droits humains. L'article signale aussi l' importance du suivi adéquat de tout appel pour une implication plus assidue et des actions plus définies dans ce domaine.
\end{abstract}

The UN Commission on Human Rights, which meets each spring in Geneva, provides one of the few opportunities within the UN system for formally linking refugees and internally displaced persons (IDPs) with human rights. It focuses on the abuse of human rights as a cause of forced displacement, and on the human rights of refugees and IDPs themselves. Of

Tim Wichert is a lawyer who works on refugee issues at the Quaker Office to the United Nations, Geneva, Switzerland. particular importance are the resolutions on Mass Exoduses and IDPs, and the statement of the UNHigh Commissioner for Refugees (UNHCR).

The Commission resolution entitled "Human Rights and Mass Exoduses," first introduced by Canada in 1980, has traditionally embodied refugee issues. It has consistently reiterated the UN General Assembly resolution 41/70 of December 1986, calling upon all States to promote human rights and fundamental freedoms and to refrain from denying these to individuals in their population because of nationality, ethnicity, race, religion or language. In 1996 , the Commission added gender to this list.

This year, much stronger human rights language was added, in particular stressing the principle of nonrefoulement and gender-specific violations of human rights, A new paragraph expresses "distress" at the "widespread violation of the principle of non-refoulement and the rights of refugees." Another new paragraph emphasizes the responsibility of all States and international organizations to cooperate with those countries actually affected by mass exoduses. This is the language of "international solidarity and burden-sharing" which the UNHCR Executive Committee is using as well. Finally, another new paragraph welcomes the work of the High Commissioner for Human Rights in creating an environment viable for return in post-conflict societies, noting initiatives such as rehabilitation of justice systems, creating national human rights institutions, human rights education, and strengthening local NGOs.

IDPs were first dealt with substantively by the Commission in 1991, and in 1992 the Commission requested the Secretary-General to appoint a Representative for IDPs. As a result of the work of the Representative, Dr. Francis
Deng, international awareness of the existence of IDPs has increased substantially.

The Commission resolution on "Internally Displaced Persons" continues to be the main focal point for IDP work within the UN system. Last year Deng submitted a significant Compilation and Analysis of Legal Norms, ${ }^{1}$ and the Commission this year called for its "rapid" publication in all the UN's working languages. ${ }^{2}$ Deng is in the midst of preparing "Guiding Principles" for IDPs based on the Compilation, which the Commission continues to encourage. And he has visited 12 countries to date to look at internal displacement. In 1997 , the Commission as boldly as possible called upon those Governments with IDPs which have not asked for or allowed a visit by Deng to do so.

This year's statement by Sadaka Ogata, the UN High Commissioner for Refugees, ${ }^{3}$ was particularly strong on refugee protection. She emphasized that "the system of refugee protection fits into, supports and is indeed an indispensable part of the global human rights regime." She went on to say that as long as people cannot have their basic human rights protected in their own country, as long as their "right to remain" cannotbe guaranteed, asylum remains the most effective means for protection.

There are other Commission resolutions and reports which link refugees, IDPs and human rights. Russia introduced a new resolution on the arbitrary deprivation of nationality, a key issue in the republics of the former Soviet Union. There are country specific situations such as Rwanda, Burundi, Zaire, Sudan, Myanmar and Afghanistan, as well as thematic issues such as torture, violence against women, and extrajudicial, summary and arbitrary executions. These can be very useful for advocacy and as 
sources of information, in particular because all relevant rapporteurs, working groups, experts and treaty bodies are called upon to pay particular attention to issues of both mass exoduses and internal displacement.

To some extent therefore, issues relating to refugees and displaced have become "mainstreamed" within the Commission. In order for the link with human rights to become stronger, there must be appropriate follow-up to the calls for action.

UNHCR is well-placed to do this, as the international guardian of the human rights of refugees. But it actually provides no follow-up system, and often needs to be reminded itself that refugee protection is based on human rights. The UN Refugee Convention requires reporting about implementation of the Convention and other legislation aimed at ensuring human rights standards for refugees, but there has been little commitment by either UNHCR or States to follow through. As a result, the Commission "encourages" greater commitment to these reporting procedures.

The Commission could enhance the work of both UNHCR and the Representative on IDPs by focusing its attention on issues of "forced displacement," rather than dividing its attention between mass exoduses and internally displaced. Through a combined resolution, a new Special Repre

sentative could provide a high-level focal point within the human rights system able to engage in the requisite political discussions. Such a person could also urge UNHCR to enhance its contribution to the Commission's human rights mechanisms, and to ensure

further that UNHCR's actions are in line with its rhetoric.
The UN Centre for Human Rights must strengthen its follow-up programs. If they can prevent the violation of human rights which cause refugee movements, through monitoring or more broadly through human rights development and rehabilitation initiatives, then they would be seen as a more relevant actor.

Finally, NGOs and other refugee advocates must see the potential of such UN processes, and be prepared to participate. Written and oral submissions can be made, and there are numerous opportunities for personal advocacy. Further, the resolution on Mass Exoduses calls for NGOs to provide information for the annual report on Mass Exoduses prepared by the High Commissioner for Human Rights.4 Invariably, NGOs are the ones that not only raise important concerns in the first place, but also try to ensure that Governments and UN agencies put into practice what they preach.slD

Notes

1. UN Doc. No. E/CN.4/1996/52/ Add.2. 2.

Arabic, Chinese, English, French, Span ish, Russian.

3. Statement given 1 April 1997. Available at http://www.unhcr.ch or http:/ / www.unhchr.ch. which are respectively the Internet sites of the UN High Commissioner for Refugees and the UN High Commissioner for Human Rights.

4. This year's report was UN Doc. No. E/ CN.4/1997/42. CI

5. For the 1997 Commission on Human Rights, the Quaker UN Office prepared a written statement on mass exoduses, another on internally displaced persons, and an oral statement entitled "Human Rights, Mass Exoduses and Displaced Persons: Seven Practical Steps." CI

\section{Legitimate and Illegitimate Discrimination: New Issues in Migration}

\author{
Edited by HowardAdelman
}

ISBN 1-55014-238-0. 1995.

287 pp., indexed. \$22.95

Freedom of movement: If the member of a .state are forced to flee, the legitimacy of that government is questionable. On the other hand, if member . canoot or Inust leave, again the goV'ernmentis not democratically legitimate.

Immigralion control: While limiting access and determining who mayor may not become members of a sovereignstate. remains a legitimate prerogative of the state, the criteria, rules and processes for doing so must be compatible With its character as a democratic state.

Legitimate and I/tegitimateDiscriminatibn:New Issues in Migration, edited by Professor Howard Adelman, deals with the question of legitimacy with cases studies from theDeveloping World, Europe, Australia, the Urnted States, and Canada.

CONTRIBUTORS:

Rainer Baub\&k, Howard Adelman, $\mathrm{G}<$ thnKibreabi A. EssumanJohns<:.:m, Grant M. Farr, Lawrence Lam, Oscar Schiappa-Pietra, Tomas Hammar, FrederiQ[iberghien (in French), .10is Foster, and Arthur C. Helton.

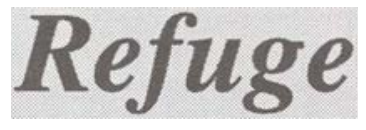

\author{
Canada's Periodical on Refugees is publishedsix.times a year by \\ the QenttefQ . f1.1g eSf;udi s YoJtkUmvetSity Toronto.
}

Available from:

Centre fot Refugee Studies

f :(41.6)736;5837

Email: refuge@yorku.ca
Tel.: (416) 736-5843 


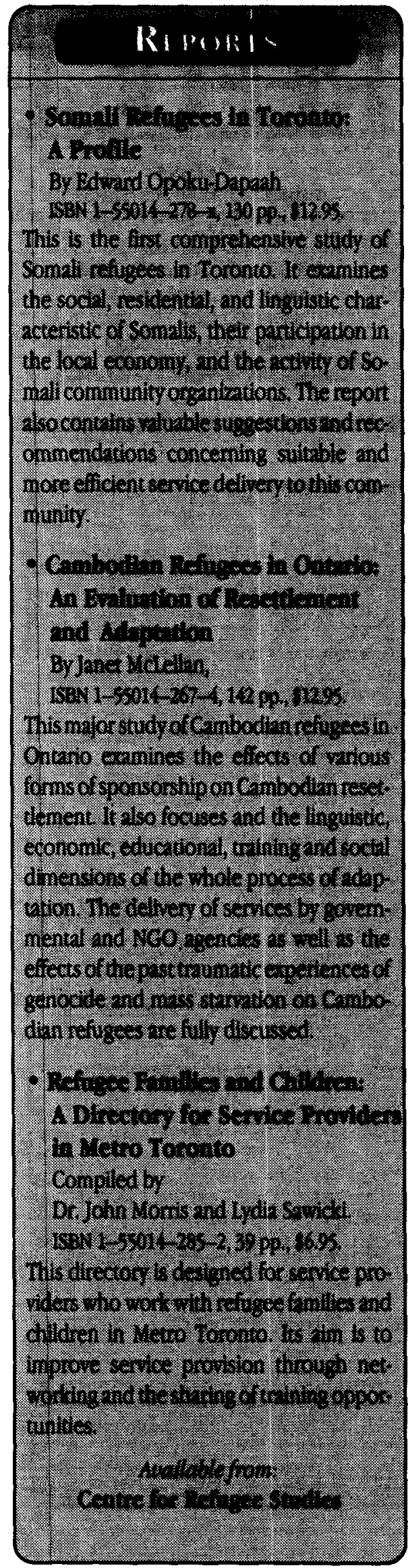

\section{Back Issues of Refuge}

The following is a list of general and thematic issues of

Refuge-Canada's periodical on refugees.

1. Environmental Refugees, Vol. 12, No. 1, June 1992.

2. Discussion of Immigration Bill C-86, Vol. 12, No. 2, July/(Aug.) 1992.

3. General Issue/Refugee Sponsorship, Vol. 12, No. 3, Sept. 1992.

4. Eastern European Refugees, Vol. 12, No. 4, Oct. 1992.

5. The Tragedy of Somalia, Vol. 12, No. 5, Nov./Dec. 1992.

6. The Review of Rejected Refugee Claims in Canada, Vol. 12, No. 6, Jan. 1993.

7. Russia and Central Eurasia, Vol. 12, No. 7, February 1993.

8. Africa Issue: Repatriation, Vol. 12, No. 8, March 1993.

9. General Issue/Globalization, Vol. 13, No. 1, April 1993.

10. Russia and Central Eurasia, Vol. 13, No. 2, May 1993.

11. Special Issue on Sri Lanka, Vol. 13, No. 3, June 1993.

12. Gender Issues and Refugee Law, Vol. 13, No. 4, July/Aug. 1993.

13. Southeast Asian Refugees, Vol. 13, No. 5, Sept. 1993.

14. Mozambican Refugees, Vol. 13, No. 6, October 1993.

15. Russia and Central Eurasia, Vol. 13, No. 7, Nov./Dec. 1993.

16. General Issue/Sudan, Vol. 13, No. 8, January 1994.

17. Integration of Refugees-The Canadian Experience, Vol. 13, No. 9, Feb. 1994.

18. Refugees and Peace in Central America, Vol. 13, No. 10, March 1994.

19. Horn of Africa, Vol. 14, No. 1, April 1994.

20. The Russian Federation, Vol. 14, No. 2, May 1994.

21. The Former Yugoslavia, Vol. 14, No. 3, June/July 1994.

22. General Issue/IRB and Rebuilding Trust/Tamil Immigrants in Canada, Vol. 14, No. 4, Aug./Sept. 1994.

23. Rwandan Crisis, Vol. 14, No. 5, October 1994.

24. Refugee Resettlement in Israel, Vol. 14, No. 6, Nov. 1994.

25. Refugee Women-Part 1: Issues, Vol. 14, No. 7, Dec. 1994.

26. Refugee Women-Part 2: Case Studies, Vol. 14, No. 8, Jan. 1995.

27. The Safe Third Country Concept, Vol. 14, No. 9, February 1995.

28. Special Issue on Chechnya, Vol. 14, No. 10, March 1995.

29. Reformulation of International Refugee Law, Vol. 15, No. 1, 1996.

30. Environment, Development and Refugees, Vol. 15, No. 2, 1996.

31. International Intervention in Refugee Crises, Vol. 15, No. 3, 1996.

32. Early Warning on Humanitarian Crises, Vol. 15, No. 4, 1996.

33. Child Refugees, Vol. 15, No. 5, 1996.

34. Global Settlement Services, Vol. 15, No. 6, 1997.

35. Early Warning and Early Response, Vol. 16, No. 1, May 1997.

36. Uprooting and Consequences, Vol. 16, No. 2, June 1997.

37. Development-induced Displacement, Vol. 16, No. 3, August 1997.

Single copy: Vol 12, $13 \& 14-\$ 6.50$; Vol 15-\$10. 10 percent discount on 3-9 issues (copies); 20 percent discount on 10 issues (copies) or more. Special discounts are available for students and exclusively volunteer-run NGOs. P. O. accepted.

Please send your orders to:

Centre for Refugee Studies, York University

Suite 333, York Lanes, 4700 Keele Street

Toronto, Ontario, M3J 1P3, Canada

Fax: (416) 736-5837 • Email: refuge@yorku.ca 
Refuge Centre for Refugee Studies Suite 322, York Lanes York University 4700 Keele Street, Toronto Ontario, Canada M3J 1P3 Phone: (416) 7365663 Fax: (416) 736-5837

Email: refuge@yorku.ca

\section{GALL FOR PAPERS}

\section{REFUGEES, RACISM, AND THE MEDIA}

The Centre fo('.;R fugee Studies will soon publish AA iss:ue of Rejugeon."Refugees, Racism, and the Media!' The issue will address topics such as:

- Portrayals ofXefugee Cotnmunities in the popular media

- Racism in the context of refugee resettlement

- Community efforts to redress media stereotyping and negative portrayal of refugees

Contributions with abstracts are invited. They mu l be received not later than April 10, 1998.

Papers shoUld be typed, double-spaced, and referenced in proper academic form. They shoUld not exceed

16 pages or about 4000 words. Short papers of about 900 words are also w lcoIQed. Word-processed submissions maybe sent on disc or by email.

Les redacteurs acceptent aussi des articles enfranfais.Le style doit conformer aux normes exiges pour les articles rediges en anglais.

Deadline: A.pril 10,1998.

For further details, please contact:

\section{Dr. Edward Opoku-Dapaah}

Guest Editor, Rejuge

Centre for Refugee Studies, York University

Suite 322, York Lanes

Toronto, Ontario, Canada M3J 1P3

Fax: (416) 736-5837 · Tel.: ( J6) 736-5663

Bmail: refuge@yorku.ca 